\title{
Methicillin resistant Staphylococcus aureus - importance of appropriate empirical therapy in serious infections
}

\author{
Pavan Kumar Nanchary Reddy ${ }^{1}$, Anand Sutar ${ }^{2}$, Sambit Sahu $^{3}$, Bini Thampi ${ }^{4}$, \\ Neha Keswani ${ }^{4}$, Kapil D. Mehta ${ }^{4 *}$
}

\begin{abstract}
${ }^{1}$ Department of Critical Care Medicine, Care Hospitals, Hyderabad, Telangana, India
${ }^{2}$ Department of Critical Care Medicine, Apollo Hospital, Sheshadripuram, Bengaluru, Karnataka, India ${ }^{3}$ Department of Critical Care Medicine, KIMS Hospital, Secunderabad, Hyderabad, Telangana, India

${ }^{4}$ Department of Medical Affairs, Wockhardt Ltd., BKC, Mumbai, Maharashtra, India
\end{abstract}

Received: 15 November 2021

Accepted: 09 December 2021

\author{
*Correspondence: \\ Dr. Kapil D. Mehta, \\ E-mail: KapilM@wockhardt.com
}

Copyright: ( $)$ the author(s), publisher and licensee Medip Academy. This is an open-access article distributed under the terms of the Creative Commons Attribution Non-Commercial License, which permits unrestricted non-commercial use, distribution, and reproduction in any medium, provided the original work is properly cited.

\begin{abstract}
India has been titled the capital of antimicrobial resistance in the world with the centre for disease dynamics, economics and policy (CDDEP) predicting two million deaths in India by 2050. As per the World Health Organisation's global priority pathogen list of 2017, methicillin resistant Staphylococcus aureus (MRSA) has been classified as a 'high priority' pathogen due to its association with increased mortality rate, rising prevalence of resistance and increased burden on healthcare settings. A recent report by Indian Council of Medical Research signifies the exponential rise in the prevalence of MRSA in India, from 29\% in 2009 to $39 \%$ in 2018. Serious MRSA infections are commonly associated with poor clinical outcomes coupled with increased hospitalisation stay and cost. Therefore, early identification and appropriate empiric treatment of MRSA plays a crucial role in healthcare settings. However, the constant rise in multi-drug resistance to the currently available anti-MRSA agents as well as their compromised safety profile limits its clinical use to manage severe MRSA infections. This review article explores the implications of severe MRSA infections and inappropriate empirical therapy on the clinical as well as economic outcomes. In addition, it also highlights limitations of the currently available anti-MRSA agents and the need for newer agents to manage multi drug resistant (MDR) gram positive infections.
\end{abstract}

Keywords: Methicillin-resistant Staphylococcus aureus, Prevalence, Appropriate empiric therapy, Anti-MRSA agents, Levonadifloxacin

\section{INTRODUCTION}

Antimicrobial resistance (AMR) has been on the rise globally posing significant concerns; as per the latest United Nations (UN) report, by 2050, 10 million deaths each year would be attributed to AMR. ${ }^{1}$ Among the multidrug resistant (MDR) gram positive pathogens, methicillin-resistant Staphylococcus aureus (MRSA) has emerged as a serious threat. ${ }^{2}$ In 2017, World Health Organisation's (WHO) global priority pathogen list labelled MRSA as a 'high priority' pathogen owing to its association with higher mortality rate, increasing health care and community burden along with the rising prevalence of resistance.

MRSA is identified with worse clinical outcomes than methicillin-sensitive S. aureus (MSSA) and has a mortality risk two-times higher. ${ }^{3,4}$ The 2014 report on antimicrobial resistance from WHO highlighted variation in the prevalence of MRSA worldwide: African region (12 to $80 \%$ ), American region (21 to $90 \%)$, European region (0.3 to $60 \%$ ), South-East Asia region (2 to $81 \%) .{ }^{5}$ In 2018 , antimicrobial resistance group of Indian Council of Medical Research reported an overall MRSA prevalence 
of $37.3 \%$, ranging from $21 \%$ to $45 \%$ indicating varied levels of prevalence across the country. ${ }^{6}$

Early identification and appropriate treatment of MRSA is an essential priority in all healthcare settings. However, in treating suspected MRSA infections, initial empirical therapy plays a crucial role. The infectious disease society of America and the United Kingdom practice guidelines recommend various treatments such as vancomycin, linezolid, clindamycin and co-trimoxazole for treating MRSA infections. ${ }^{7,8}$ However, the rising resistance to the current anti-MRSA agents render them incapable of managing severe MRSA infections. The Indian network for surveillance of antimicrobial resistance (INSAR) group identified MRSA to be highly susceptible (100\%) towards vancomycin and linezolid while exhibiting decreased sensitivity towards clindamycin $(53.4 \%)$, erythromycin (29.2\%) and co-trimoxazole (44.4\%). ${ }^{9}$ Emerging reports of rising multi drug resistance across the country, also challenge the use of such drugs as empirical therapy. ${ }^{10-13}$ Moreover, not only the susceptibility pattern but the selection of the empiric antibiotic especially for critically ill patients is also the key essence for a positive clinical outcome in such patients. Various reports over the years have shown a significantly positive correlation between inappropriate empirical therapy, mortality rates and hospitalisation cost in patients infected with resistant strains. In this review, we explore the current role of empirical therapy, the clinical and economic outcomes of MRSA infections, impact of inappropriate empirical therapy and pitfalls of existing treatments. This article explores newer agents of potential empiric usage in the management of MRSA infections.

\section{Methicillin resistant $S$. aureus: public health concern in India}

MRSA is a critical nosocomial gram positive pathogen in the Indian ICUs and the community. It can be categorised into community acquired (CA-MRSA) or hospital acquired (HA-MRSA) infections. CA-MRSA is majorly involved in skin and soft tissue infections (SSTIs) such as wound infection, abscesses or cellulitis. Traditionally, it was thought that HA-MRSA causes infections upon prolonged hospitalisation, in patients with indwelling devices or in patients undergoing dialysis or receiving immunosuppressive therapy. However, it is increasingly being observed worldwide, including in India, that CAMRSA is gradually resembling HA-MRSA in being more invasive and transmissible than before. However, inappropriate empirical therapy can lead to serious invasive infections like bone and joint infections, necrotizing pneumonia and septicaemia. Furthermore, a recent evolution and global transmission of MRSA has led to the emergence of MDR CA-MRSA lineage from the Indian subcontinent, known as the Bengal Bay clone (ST772). This was first isolated from Bangladesh and India in 2004 and is highly virulent and resistant to multiple classes of antibiotics such as $\beta$-lactams, fluoroquinolones, macrolides and aminoglycosides due to the acquisition of Panton-Valentine leukocidin (PVL). ${ }^{14-16}$ Its ability to acquire multidrug resistance, to penetrate in hospital settings and association with severe manifestations like necrotizing pneumonia and bacteraemia highlights Bengal bay clone as a major public health concern in the Indian subcontinent. ${ }^{17}$

\section{Risk factors predisposing a serious MRSA infection}

A recent study from North India displayed a strong association between MRSA infection and comorbid conditions. The probability of acquiring a serious MRSA infection was increased 3.5-fold with use of invasive devices and 2-fold in cases of previous hospitalisations, as compared with MSSA infected patients. ${ }^{18}$ Additionally, Chatterjee et al highlighted prior respiratory infections and bacteraemia as significant risk factors of MRSA in his study. ${ }^{19}$ Furthermore, prior antibiotic use or drug abuse is an established threat for multi-drug resistant MRSA, which subsequently may lead to more invasive infections. ${ }^{20}$ Older age, diabetes mellitus and chronic kidney disease are commonly seen in association with MRSA infections. ${ }^{21}$ Other commonly associated risk factors for MRSA infections are haemodialysis, open wounds and long-term central venous access or long-term urinary catheter. ${ }^{22}$

\section{Clinical outcome in patients infected with MRSA}

\section{Mortality with MRSA infection}

Over the years, several studies have highlighted the dominating impact of MRSA on the mortality rates when compared with patients infected with methicillin sensitive S. aureus strains (MSSA). Additionally, the EPIC II point prevalence study in critically ill patients had reported a $50 \%$ higher chance of hospital death in patients with MRSA. ${ }^{23}$ Similarly, a study by Chen et al in $S$. aureus bacteraemia patients showed that MRSA was associated with increased mortality risk. $^{24}$ A recent comparative review of MRSA and MSSA septic arthritis found that MRSA was associated with increased risk of all-cause mortality which subsequently leads to increased risk of disability. ${ }^{25}$

\section{Hospitalization stay and cost}

MRSA not only affects the mortality rates but also has a major impact on the hospital stay, intensive care admission, number of complications and the cost incurred to the patients. Chatterjee et al showed that patients with MRSA infection had longer duration of hospital stay (14 days versus 8 days), antibiotic prescription (20 days versus 14 days) coupled with an increased greater need for ICU care (40\% versus $14 \%$ ) and length of ICU stay (5 days versus 2 days) than patients with MSSA. ${ }^{17}$ Additionally, several reports globally have established that MRSA positive patients require longer hospital stay when compared to patients with MSSA infections. ${ }^{26-28} \mathrm{~A}$ recent study from Norway showed that not only was the length of 
hospital stay 8 times longer in MRSA group but also the hospitalisation costs were significantly higher as compared to non-MRSA inpatients. ${ }^{29}$ A similar study from Swiss university hospital showed that an average bed day cost for MRSA infected patients was 1.5 times higher than noninfected patients admitted in the wards. ${ }^{30} \mathrm{~A}$ multicentre study from China associated MRSA infections to an increased mortality of $0-3.5 \%$, increased hospital stay of 6-14 days and escalated hospital cost ranging from $\$ 3,220$ to $\$ 9,606 .{ }^{31}$ Several studies from Europe and US that investigated the MSSA and MRSA investigation found an additional attributable cost of $€ 8,000$ to $€ 17,000$ and US $\$ 13,900$ respectively. ${ }^{32}$

\section{PROPHYLACTIC EMPIRICAL ANTIBIOTIC THERAPY FOR MRSA: CURRENT RECOMMENDATIONS}

Table 1 summarizes the recommendation from the Infectious Diseases Society of America (IDSA) guidelines and the Ministry of Health and Family Welfare (MoHFW), India on the prophylactic empirical use of antimicrobials for MRSA infection. ${ }^{6,33}$ The UK health practice guidelines also focussed on community associated severe MRSA infections. For SSTIs, these guidelines recommend the use of rifampicin and sodium fusidate or doxycycline for 5-7 days. Trimethoprim combined with rifampicin (5-7 days) and linezolid are also recommended. For pneumonia, linezolid and high-dose clindamycin with or without rifampicin has been advised. ${ }^{8}$ From India, the 2019 national guidelines for antibiotic prescription in ICU recommends empiric antibiotic therapy covering MRSA for serious infections like community-acquired pneumonia (CAP), ventilator associated pneumonia, catheter related blood stream infections, bone and joint infections and sepsis of unknown cause. For CAP suspected to be associated with MRSA, vancomycin or teicoplanin are advised in the regimen. Patients resistant to vancomycin or with associated renal failure should be initiated with linezolid therapy. In case of ventilator-associated pneumonia (VAP) with high risk of MDR pathogens (MRSA prevalence of $>15 \%$ and gram-negative prevalence of $>10 \%$ ), an empirical antibiotic coverage against MRSA and gram negative pathogen is recommended. In treating nosocomial meningitis, vancomycin in combination with cefepime/ceftriaxone/ meropenem is recommended. For brain abscess, vancomycin was advised in cases with suspicion of MRSA. It further recommends piperacillin-tazobactam (pipe-tazo) plus vancomycin/teicoplanin/daptomycin/ linezolid for severe non-purulent SSTIs. Linezolid was recommended to be used restrictively due to its inclusion in the treatment guidelines of tuberculosis in India. ${ }^{34}$

This is reflected in the recommendation from MoHFW, India; where linezolid was not advised in majority of MRSA infections. For most of the MRSA related infections, vancomycin has been identified as a primary empiric antibiotic of choice. ${ }^{7}$

\section{IMPORTANCE OF APPROPRIATE EMPIRIC THERAPY IN MRSA}

As the microbiological results take 24-72 hours, an appropriate empiric therapy plays a crucial role in determining a positive clinical outcome of critically ill patients. The choice of empiric therapy is determined by the likelihood of pathogen involved, resistance pattern, severity of illness, site of infection and comorbidities. ${ }^{35} \mathrm{~A}$ SPA-BACT survey from 121 French hospitals emphasized that rapid initiation of appropriate treatment reduces shortterm mortality in bloodstream infections. ${ }^{36}$

A meta-analysis conducted to explore the use of inappropriate antibiotic therapy in patients with severe infection showed that the inappropriate usage ranged from $14-79 \%$ across various studies with an incidence rate of more than $50 \%$. This was further correlated with significantly increased 28 day and 60 day mortality $(p \leq 0.02)$ in patients who received inappropriate antibiotic therapy. ${ }^{37}$ Similarly, various reports have highlighted that increased morbidity and mortality rates with inappropriate empiric therapy (IET), have led to clinical and economic outcomes to a higher degree. Table 2 summarizes the studies reporting clinical outcomes with IET in MRSA. In a study involving patients of $S$. aureus bacteraemia (SAB), Kim et al observed that mortality was higher in patients receiving IET than an appropriate empiric therapy (AET) $(39 \%$ versus $28 \%$, odds ratio $(\mathrm{OR})=1.60, \mathrm{p}=0.09) .{ }^{38}$ Another study from Thailand reported that delayed therapy or IET was significantly associated with increased allcause mortality $(\mathrm{p}<0.001)$ and attributable mortality. ${ }^{39}$ Similarly, in 510 episodes of MRSA bacteraemia, significantly higher 30-day mortality was observed in IET than AET $(49.1 \%$ versus $33.3 \%$, OR=2.15, $\mathrm{p}=0.001) .{ }^{40}$ Further, in patients with septic shock, 28-day mortality was significantly higher with IET $(61.6 \%$ versus $41.9 \%$, $\mathrm{p}=0.017$ ) than in $\mathrm{AET}^{41}$ A systematic review involving 70 prospective studies in patients with sepsis showed that among $46.5 \%$ of patients administered with IET, the mortality rate was $35 \%$. IET was associated with significantly higher mortality in both unadjusted $(\mathrm{OR}=2.11)$ and adjusted $(\mathrm{OR}=2.05)$ comparisons. ${ }^{42}$ Another study from $\mathrm{Wi}$ et al demonstrated that compared to MSSA bacteraemia, IET in patients with MRSA bacteraemia was associated with a higher mortality rate (56.5\% versus $2.6 \%, \mathrm{p}<0.001) .{ }^{43}$ This evidence clearly suggests an increased risk of mortality with IET in MRSA infections. In addition to mortality, IET in MRSA infections can alter other clinical outcomes. A study from Zilberberg et al in patients with HA-cSSTI (MRSA in nearly $30 \%$ cases) demonstrated that IET resulted in a significantly higher frequency of decubitus ulcer, devicerelated infection, bacteraemia, and increased prolongation of hospital stay. ${ }^{44}$ A cohort study from South western India also showed that IET was significantly associated $(\mathrm{p}=0.006)$ with adverse outcomes. ${ }^{19}$

Inappropriate therapy is also associated with increased hospital stay which eventually leads to increased cost for 
critically ill patients. An initial appropriate therapy was associated with reduced length of hospital stay (7.1 versus 9.3 days, $\mathrm{p}=0.05)$ and decreased median crude cost ( $\$ 13,688$ versus $\$ 19,427 ; p=0.01)$ as compared to patients on initial inappropriate therapy. ${ }^{45} \mathrm{~A}$ similar study on patients with complicated intra-abdominal infection reported an additional 5.3 hospitalised days and \$3,287 additional hospital cost incurred to patients with failed initial empirical antibiotic therapy. ${ }^{46}$

The importance of appropriate empirical antibiotic therapy is not restricted to in-patients but is equally vital in the outpatient setting as well. In a study from the ambulatory clinic, Szumowski et al demonstrated that the sensitivity of the pathogen to empiric antibiotic therapy in MRSASSTI was associated with better clinical resolution $(\mathrm{OR}=5.91) .{ }^{47}$ Another study reported higher rates of treatment failure in MRSA cellulitis if the strains were not sensitive to the initial empirical antibiotic $(71 \%$ versus $47 \%, \mathrm{p}<0.001) .{ }^{48}$

\section{LIMITATIONS OF EXISTING ANTI-MRSA AGENTS AS EMPIRIC TREATMENTS}

Currently, various agents are available for the initial empirical management of MRSA infections. Vancomycin and Teicoplanin are the most commonly used antibiotic for the empirical management of most MRSA infections. Other agents include clindamycin, TMP-SMX, linezolid, daptomycin and newly approved ceftaroline and telavancin which are used for the treatment of gram positive infections. However, these agents have certain limitations which restrict their clinical use in patients suffering from pneumonia, bone and joint infections, diabetic foot infections (DFI) and blood stream infections (BSI). ${ }^{49}$ Table 3 summarizes the common limitations of the currently available anti-MRSA agents approved in India.

\section{NEWER DRUGS FOR MRSA}

With increasing resistance to existing antibiotics, there is a need to research and develop novel therapies to manage MRSA infections. There has been substantial progress in identifying newer antibiotics that can effectively manage MRSA. Ideal empiric agent should possess the favorable pharmacokinetic (PK) and pharmacodynamics (PD) profiles, should be active against a wide range of pathogens, be safe and tolerable and available as an oral as well as parenteral formulation. Here, we briefly discuss recent novel therapies with a potential for usage as an empirical antibiotic in MRSA infections.

\section{Newer approved anti-MRSA agents in India}

\section{Ceftaroline}

Ceftaroline fosamil is an injectable fifth generation cephalosporin which has been approved for the treatment of adult patients with acute bacterial skin and skinstructure infections, community-acquired bacterial pneumonia (CABP) and concurrent bacteremia in India (year: 2016). Ceftaroline has activity against MRSA, penicillin resistant streptococcus spp. and respiratory gram negative pathogens like Haemophilus influenzae and Moraxella catarrhalis. It has potential benefit in the treatment of severe and refractory MRSA infections of various organ systems and is well tolerated. However, recent safety studies have shown agranulocytosis as an adverse event complicating $13 \%$ of treatment courses and long term therapy is associated with increased risk of neutropenia. $^{50}$ Ceftaroline has poor lung tissue concentration, with only $23 \%$ of the initial dose reaching the epithelial lining fluid and being a $\beta$-lactam agent, it does not have activity against atypical respiratory pathogens and hence, cannot be used as monotherapy in CABP patients with suspected involvement of atypical pathogens. ${ }^{51}$

\section{Levonadifloxacin}

Of all the newer anti- MRSA agents, Levonadifloxacin is the only one that has been indigenously researched, developed and approved in India. Levonadifloxacin (intravenous) and alalevonadifloxacin (oral prodrug) are broad spectrum, benzoquinolizine subclass of quinolones which have potent antimicrobial activity against quinolone-resistant $S$. aureus (QRSA), MRSA and hVISA isolates. It has recently been granted approval for indications; ABSSSI, diabetic foot infections (DFI) and concurrent bacteraemia. Spectrum of activity against MDR gram-positive, quinolone-susceptible gramnegative, anaerobes and atypical pathogens suggest their potential utility in resistant polymicrobial infections. It has rapid bactericidal activity against MRSA and QRSA even under high bacterial density. In a comparative study, levonadifloxacin exhibited anti-biofilm activity where it showed consistent killing of MRSA and QRSA embedded biofilms when compared with other agents which showed static or variable cidal action. ${ }^{52}$ Additionally, unlike other fluoroquinolones that deteriorate in acidic conditions, levonadifloxacin exhibited enhanced activity in a $\mathrm{pH}$ of 5.5 which increases its therapeutic potential in intracellular infections and other clinical conditions with acidic environment. ${ }^{53}$

Levonadifloxacin has been reported to have excellent lung tissue penetration along with superior PK/PD profile coupled with immunomodulatory property where it attenuates TNF $\alpha$ and IL-6 production. ${ }^{54,55}$ This characteristic property bestows levonadifloxacin with favourable clinical outcomes in MRSA pneumonia. Moreover, narrow mutant selection window and not being a substrate of NorA efflux pump, imparts levonadifloxacin with an enhanced resistance suppression potential. Therefore, levonadifloxacin has a strong potential for empiric management of serious infections with suspected MRSA. Table 4 elucidates efficacy and adverse events between currently available anti-MRSA agentslevonadifloxacin, vancomycin, teicoplanin, linezolid, daptomycin and ceftaroline. 
Table 1: Guideline recommendations on initial antibiotic therapy for MRSA in adults.

\begin{tabular}{|c|c|c|}
\hline MRSA infection & IDSA $^{7}$ & MOHFW, India ${ }^{33}$ \\
\hline \multicolumn{3}{|l|}{ SSTIs } \\
\hline SSTIs & Clinda, TMP-SMX, Doxy/Mino, Linez (1-2 weeks) & - \\
\hline cSSTIs & Vanco, Linez, Dapto, Telavan, Clinda (1-2 weeks) & - \\
\hline \multicolumn{3}{|l|}{ Bacteraemia } \\
\hline Uncomplicated & Vanco, Dapto (2 weeks) & - \\
\hline Complicated & Vanco, Dapto (4-6 weeks) & - \\
\hline \multicolumn{3}{|l|}{ Infective endocarditis } \\
\hline Native valve & Vanco, Dapto (6 weeks) & Vanco (6 weeks) \\
\hline Prosthetic valve & Vanco + Rifa (6 weeks) + Genta (2 weeks) & $\begin{array}{l}\text { Vanco + Genta (only } 2 \\
\text { weeks) + Rifa (6-8 weeks) }\end{array}$ \\
\hline \multicolumn{3}{|l|}{ Pneumonia } \\
\hline HA or CA-MRSA & Vanco, Linez, Clinda (1-3 weeks) & $\begin{array}{l}\text { Vanco + Cefta, Vanco + } \\
\text { Pipe-Tazo (1 week) }\end{array}$ \\
\hline \multicolumn{3}{|l|}{ Bone and joint infections } \\
\hline Osteomyelitis & $\begin{array}{l}\text { Vanco, Dapto, TMP-SMX + Rifa, Linez, Clinda (8 } \\
\text { weeks) }\end{array}$ & $\begin{array}{l}\text { Vanco, TMP-SMX + Rifa } \\
\text { (4-6 weeks) }\end{array}$ \\
\hline Septic arthritis & $\begin{array}{l}\text { Vanco, Dapto, TMP-SMX + Rifa, Linez, Clinda (3-4 } \\
\text { weeks) }\end{array}$ & $\begin{array}{l}\text { Vanco, TMP-SMX + Rifa } \\
\text { (4-6 weeks) }\end{array}$ \\
\hline Device related & $\begin{array}{l}\text { [Vanco, Dapto, Linez, Clinda] + Rifa }(2 \text { week }) \text { f/b Rifa } \\
+[\text { FQ, TMP-SMX, Tetra, Clinda] (3-6 months) }\end{array}$ & $\begin{array}{l}\text { Based on actual sensitivity } \\
\text { ( } 6 \text { weeks- } 6 \text { months) }\end{array}$ \\
\hline \multicolumn{3}{|l|}{ CNS infections } \\
\hline Meningitis & Vanco \pm Rifa (2 weeks), Linez, TMP-SMX & Vanco (7-10 days) \\
\hline Brain/spinal epidural abscess & Vanco \pm Rifa (4-6 weeks), Linez, TMP-SMX & \\
\hline $\begin{array}{l}\text { Septic thrombosis of sinus } \\
\text { (dual venous/cavernous) }\end{array}$ & Vanco \pm Rifa (4-6 weeks), Linez, TMP-SMX & \\
\hline
\end{tabular}

SSTI: Skin and soft tissue infections; cSSTI: complicated skin and soft tissue infections; Clinda: clindamycin; TMP-SMX: trimethoprimsulphamethoxazole; Doxy/Mino: doxycycline/minocycline; Linez: linezolid; Vanco: vancomycin; Dapto: daptomycin; Telavan: telavancin; Rifa: rifampicin; Genta: gentamycin; Cefta: ceftaroline; Pipe-Tazo: piperacillin-tazobactam; FQ: fluoroquinolones; Tetra: tetracyclines

Table 2: Clinical outcomes with inappropriate empirical therapy in MRSA infections.

\begin{tabular}{|c|c|c|c|}
\hline Author (year) & Population & Groups & Outcomes \\
\hline Kim et al (2006) ${ }^{38}$ & $\begin{array}{l}\text { S. aureus bacteraemia } \\
(\mathrm{n}=238)\end{array}$ & IET versus AET & $\begin{array}{l}\text { Mortality } \\
\text { Unmatched, univariate: } 39 \% \text { versus } 28 \%(\mathrm{p}=0.09) \\
\text { Matched, multivariate: } 32 \% \text { versus } 28 \%(\mathrm{p}=0.42)\end{array}$ \\
\hline Paul et al $(2010)^{40}$ & $\begin{array}{l}\text { MRSA bacteraemia } \\
(n=510)\end{array}$ & IET versus AET & 30-day mortality: $49.1 \%$ versus $33.3 \%(\mathrm{p}=0.001)$ \\
\hline $\begin{array}{l}\text { Zilberberg et al } \\
(2010)^{44}\end{array}$ & $\begin{array}{l}\text { HA-cSSTI }(n=717) \\
(\text { MRSA 30\%) }\end{array}$ & IET versus AET & $\begin{array}{l}\text { Decubitus ulcer: } 29.5 \% \text { versus } 10.9 \%(\mathrm{p}<0.001) \\
\text { Device-associated infection: } 42.6 \% \text { versus } 28.6 \% \\
(\mathrm{p}=0.004) \\
\text { Bacteremia: } 68.9 \% \text { versus } 57.8 \%(\mathrm{p}=0.028) \\
\text { Increased length of hospital stay by } 1.8 \text { days } \\
\text { Hospital mortality: } 7.4 \% \text { versus } 6.4 \%(\mathrm{p}=0.710)\end{array}$ \\
\hline $\begin{array}{l}\text { Andersson et al } \\
(2019)^{56}\end{array}$ & $\begin{array}{l}\text { Community-onset } \\
\text { sepsis and septic } \\
\text { shock }(n=90)\end{array}$ & IET versus AET & $\begin{array}{l}\text { 28- day mortality was } 46.4 \% \text { among the high-risk } \\
\text { patients who received IET compared with } 12.5 \% \\
\text { with AET }\end{array}$ \\
\hline
\end{tabular}

MRSA: Methicillin resistant Staphylococcus aureus; IET: inappropriate empirical therapy; AET: appropriate empirical therapy; cSSTI: complicated skin and soft tissue infections 
Table 3: Limitations of the currently available anti-MRSA agents approved in India.

\begin{tabular}{|c|c|c|c|}
\hline Treatment & Mechanism of action & Spectrum/cidality & Limitations \\
\hline \multirow{6}{*}{$\begin{array}{l}\text { Vancomycin } \\
58\end{array}$} & \multirow{6}{*}{$\begin{array}{l}\text { Targets cell wall synthesis } \\
\text { (Bind to terminal D-ala-D- } \\
\text { ala chains on } \\
\text { peptidoglycan in the cell } \\
\text { wall, preventing further } \\
\text { elongation of } \\
\text { peptidoglycan chains) }\end{array}$} & $\begin{array}{l}\text { Narrow spectrum } \\
\text { coverage }\end{array}$ & Nephrotoxicity \\
\hline & & Slow bactericidal & Redman syndrome \\
\hline & & & MIC creep, hVISA development \\
\hline & & & Variable tissue penetration \\
\hline & & & Dose adjustment required in renal patients \\
\hline & & & $\begin{array}{l}\text { Therapeutic drug monitoring (TDM) is } \\
\text { recommended }\end{array}$ \\
\hline \multirow{6}{*}{ Teicoplanin ${ }^{59,60}$} & \multirow{6}{*}{ Inhibits cell wall synthesis } & $\begin{array}{l}\text { Narrow spectrum } \\
\text { coverage }\end{array}$ & Nephrotoxicity \\
\hline & & Slow bactericidal & MIC creep \\
\hline & & & $\begin{array}{l}2-3 \text { days required to reach } \\
\text { therapeutic levels, even with loading dose }\end{array}$ \\
\hline & & & Variable tissue penetration \\
\hline & & & Dose adjustment required in renal patients \\
\hline & & & $\begin{array}{l}\text { Therapeutic drug monitoring (TDM) is } \\
\text { recommended }\end{array}$ \\
\hline \multirow{5}{*}{ Linezolid $^{61,62}$} & \multirow{5}{*}{$\begin{array}{l}\text { Inhibits protein synthesis } \\
\text { by binding to } 50 \mathrm{~s} \\
\text { ribosomal subunit }\end{array}$} & $\begin{array}{l}\text { Narrow spectrum } \\
\text { coverage }\end{array}$ & Thrombocytopenia \\
\hline & & Bacteriostatic & Bone marrow suppression \\
\hline & & & Peripheral and optic neuropathy \\
\hline & & & Serotonin syndrome \\
\hline & & & $\begin{array}{l}\text { Limited efficacy in bacteraemia or } \\
\text { endocarditis }\end{array}$ \\
\hline \multirow{4}{*}{ Daptomycin ${ }^{63}$} & \multirow{4}{*}{$\begin{array}{l}\text { Disrupts cell membrane, } \\
\text { leading to rapid } \\
\text { depolarization and cell } \\
\text { death }\end{array}$} & $\begin{array}{l}\text { Narrow spectrum of } \\
\text { coverage }\end{array}$ & Inactivated by pulmonary surfactant \\
\hline & & Bactericidal activity & Skeletal muscle toxicity \\
\hline & & & Potential for cross resistance with hVISA \\
\hline & & & Dose adjustment in renal patients \\
\hline \multirow{5}{*}{ Tigecycline $e^{65,66}$} & \multirow{5}{*}{$\begin{array}{l}\text { Inhibits protein synthesis } \\
\text { by binding to } 30 \mathrm{~s} \\
\text { ribosomal subunit }\end{array}$} & Broad spectrum coverage & $\begin{array}{l}\text { Not useful for lung and blood stream } \\
\text { infections }\end{array}$ \\
\hline & & Bacteriostatic & Black box warning from the USFDA for \\
\hline & & & all-cause mortality \\
\hline & & & Low serum levels \\
\hline & & & Poor tissue penetration \\
\hline \multirow{3}{*}{$\begin{array}{l}\text { Clindamycin } \\
68\end{array}$} & \multirow{3}{*}{$\begin{array}{l}\text { Inhibits protein synthesis } \\
\text { by binding to } 50 \mathrm{~s} \\
\text { ribosomal subunit }\end{array}$} & Broad spectrum coverage & $\begin{array}{l}\text { Increased constitutive and inducible } \\
\text { resistance }\end{array}$ \\
\hline & & Bacteriostatic & Clostridium difficile colitis \\
\hline & & & Antibiotic associated diarrhoea \\
\hline \multirow{4}{*}{ Rifampicin $^{69,70}$} & \multirow{4}{*}{$\begin{array}{l}\text { Inhibits bacterial DNA } \\
\text { dependent RNA } \\
\text { polymerase thereby } \\
\text { inhibiting bacterial } \\
\text { transcription }\end{array}$} & Broad spectrum coverage & Increased risk of drug interactions \\
\hline & & $\begin{array}{l}\text { Bacteriostatic/ } \\
\text { bactericidal activity }\end{array}$ & Hepatotoxicity \\
\hline & & & Rapid development of resistance \\
\hline & & & $\begin{array}{l}\text { Restriction due to TB in third world } \\
\text { countries }\end{array}$ \\
\hline \multirow{4}{*}{ Ceftaroline $^{71,72}$} & \multirow{4}{*}{$\begin{array}{l}\text { Binds to penicillin binding } \\
\text { protein (PBP2a) and } \\
\text { inhibits the synthesis of the } \\
\text { peptidoglycan layer of } \\
\text { bacterial cell walls }\end{array}$} & $\begin{array}{l}\text { Narrow spectrum } \\
\text { coverage }\end{array}$ & Poor intracellular concentration \\
\hline & & Bactericidal activity & Dose adjustment in renal patients \\
\hline & & & Cannot be used as monotherapy in CABP \\
\hline & & & Clostridium difficile-associated diarrhea \\
\hline
\end{tabular}


Table 4: Comparative efficacy and safety parameters between anti-MRSA agents. ${ }^{\text {77-72 }}$

\begin{tabular}{|c|c|c|c|c|c|}
\hline Properties & $\begin{array}{l}\text { Levonadiflox } \\
\text { acin }\end{array}$ & Vancomycin/teicoplanin & Linezolid & Daptomycin & Ceftaroline \\
\hline Dose & $\begin{array}{l}800 \mathrm{mg} \text { BID } \\
\text { (I.V) } \\
1000 \mathrm{mg} \text { BID } \\
\text { (oral) }\end{array}$ & $\begin{array}{l}\text { Vancomycin: } 0.5 \mathrm{~g} \text { QID } \\
\text { or 1g BID } \\
\text { Teicoplanin: } 400 \mathrm{mg} \text { BID } \\
\text { (loading dose); } 400 \mathrm{mg} \\
\text { OD (maintenance dose) }\end{array}$ & $600 \mathrm{mg}$ BID & $500 \mathrm{mg}$ OD & $600 \mathrm{mg}$ BID \\
\hline Spectrum & Broad & Narrow & Narrow & Narrow & Broad \\
\hline Formulation & IV and Oral & I.V only & IV and Oral & I.V only & I.V only \\
\hline Bacterial killing & Cidal & Slow bactericidal & Static & Cidal & Cidal \\
\hline $\begin{array}{l}\text { Major adverse } \\
\text { effects }\end{array}$ & None & Nephrotoxicity & $\begin{array}{l}\text { Bone marrow } \\
\text { suppression }\end{array}$ & $\begin{array}{l}\text { Muscle } \\
\text { toxicity }\end{array}$ & $\begin{array}{l}\text { Diarrhoea, } \\
\text { nausea, and } \\
\text { rash }\end{array}$ \\
\hline $\begin{array}{l}\text { Lung tissue } \\
\text { concentration }\end{array}$ & Excellent & Poor & Good & Not active & Poor \\
\hline Biofilm action & Potent & No & Moderate & No & No \\
\hline $\begin{array}{l}\text { Dose adjustment in } \\
\text { RI }\end{array}$ & No & Yes & No & Yes & Yes \\
\hline $\begin{array}{l}\text { Dose adjustment in } \\
\text { HI }\end{array}$ & No & No & Yes & No & No \\
\hline
\end{tabular}

\section{CONCLUSION}

MRSA remains a serious threat globally and necessitates timely management. Appropriate empiric therapy is a strong pillar of antibiotic stewardship in decreasing mortality, morbidity and hospitalization costs. Limitations of current antibiotics call for new and effective anti-MRSA antibiotic which can potentially be used in severe invasive infections as well as on outpatient basis. Newer antibiotics, ceftaroline and levonadifloxacin cater to the unmet clinical needs and hold promise to be considered as an appropriate initial antibiotic therapy for invasive MRSA infections. However, watchfulness will be necessary to avoid unmonitored use to prevent the development of resistance to these novel antibiotics. We look forward to more studies in these areas, especially from those countries where hospital acquired infection burden is high.

Funding: No funding sources Conflict of interest: None declared

Ethical approval: Not required

\section{REFERENCES}

1. Abou Fayad A, Itani D, Miari M, Tanelian A, Iweir S, Matar GM. From bugs to drugs: Combating antimicrobial resistance by discovering novel antibiotics. J Infect Dev Ctries. 2018;12(2.1):3.

2. Hassoun A, Linden PK, Friedman B. Incidence, prevalence, and management of MRSA bacteremia across patient populations-a review of recent developments in MRSA management and treatment. Crit Care. 2017;21(1):211.

3. Cosgrove SE, Sakoulas G, Perencevich EN, Schwaber MJ, Karchmer AW, Carmeli Y. Comparison of mortality associated with methicillin- resistant and methicillin-susceptible Staphylococcus aureus bacteremia: a meta-analysis. Clin Infect Dis. 2003;36(1):53-9.

4. Shurland S, Zhan M, Bradham DD, Roghmann MC. Comparison of mortality risk associated with bacteremia due to methicillin-resistant and methicillin-susceptible Staphylococcus aureus. Infect Control Hospital Epidemiol. 2007;28(3):2739.

5. World Health Organization. Antimicrobial resistance-Global Report on Surveillance. Available at: https://apps.who.int/iris/bitstream/handle/10665/ 112642/9789241564748_eng.pdf;jsessionid=706BB 0FB86C3CF02B0082119E4BCFD32? sequence $=1$. Accessed on 15 May 2020.

6. AMRSN Annual Report. Indian Council of Medical Research. Available at: https://www.icmr.nic.in/ sites/default/files/reports/AMRSN_Annual_Report_ 2018_0.pdf. Accessed on 14 April 2020.

7. Liu C, Bayer A, Cosgrove SE, Daum RS, Fridkin SK, Gorwitz RJ, et al. Clinical practice guidelines by the infectious diseases society of america for the treatment of methicillin-resistant Staphylococcus aureus infections in adults and children. Clin Infect Dis. 2011;52(3):18-55.

8. Nathwani D, Morgan M, Masterton RG, Dryden M, Cookson BD, French G, et al. Guidelines for UK practice for the diagnosis and management of methicillin-resistant Staphylococcus aureus (MRSA) infections presenting in the community J Antimicrob Chemother. 2008;61(5):976-94.

9. Indian Network for Surveillance of Antimicrobial Resistance (INSAR) group, India. Methicillin resistant Staphylococcus aureus (MRSA) in India: Prevalence \& susceptibility pattern. Indian J Med Res. 2013;137:363-9. 
10. Kumar M. Multidrug-resistant Staphylococcus aureus, India, 2013-2015. Emerg Infect Dis. 2016;22(9):1666-7.

11. Mohanty S, Behera B, Sahu S, Praharaj AK. Recent pattern of antibiotic resistance in Staphylococcus aureus clinical isolates in Eastern India and the emergence of reduced susceptibility to vancomycin. J Lab Physicians. 2019;11(4):340-5.

12. Husain A, Rawat V, Umesh, Kumar M, Verma PK. Vancomycin, linezolid and daptomycin susceptibility pattern among clinical isolates of methicillinresistant Staphylococcus aureus (MRSA) from SubHimalyan Center. J Lab Physicians. 2018;10(2):1458.

13. Amberpet R, Sistla S, Sugumar M, Nagasundaram N, Manoharan M, Parija SC. Detection of heterogeneous vancomycin-intermediate Staphylococcus aureus: A preliminary report from south India. Indian J Med Res. 2019;150:194-8.

14. Goering RV, Shawar RM, Scangarella NE, O'Hara FP, Amrine-Madsen H, West JM, et al. Molecular epidemiology of methicillin-resistant and methicillin-susceptible Staphylococcus aureus isolates from global clinical trials. J Clin Microbiol. 2008;46(9):2842-7.

15. Steinig EJ, Andersson P, Harris SR, Sarovich DS, Manoharan A, Coupland P, et al. Single-molecule sequencing reveals the molecular basis of multidrugresistance in ST772 methicillin-resistant Staphylococcus aureus. BMC Genomics. 2015;16(1):388.

16. Chakrakodi B, Prabhakara S, Nagaraj S, J. Etienne, G. Arakere. High Prevalence of Ciprofloxacin Resistance in Community Associated Staphylococcus aureus in a Tertiary Care Indian Hospital. Adv Microbiol. 2014;4(2):133-41.

17. Steinig EJ, Duchene S, Robinson DA, Monecke S, Yokoyama M, Laabei M, et al. Evolution and Global Transmission of a Multidrug-Resistant, CommunityAssociated Methicillin-Resistant Staphylococcus aureus Lineage from the Indian Subcontinent. mBio. 2019;10(6):e01105-19.

18. Gupta S, Mishra B, Thakur A, Dogra V, Loomba PS, Jain M, et al. Risk factors associated with MRSA. Southern Af J Infect Dis. 2018;33(3):76-9.

19. Chatterjee A, Rai S, Guddattu V, Mukhopadhyay C, Saravu K. Is methicillin-resistant Staphylococcus Aureus infection associated with higher mortality and morbidity in hospitalized patients? A cohort study of 551 patients from South Western India. Risk Manag Healthc Policy. 2018;11:243-50.

20. Hershow RC, Khayr WF, Smith NL. A comparison of clinical virulence of nosocomially acquired methicillin-resistant and methicillin-sensitive Staphylococcus aureus infections in a university hospital. Infect Control Hosp Epidemiol. 1992;13(10):587-93.

21. Engemann JJ, Carmeli Y, Cosgrove SE, Fowler VG, Bronstein MZ, Trivette SL, et al. Adverse clinical and economic outcomes attributable to methicillin resistance among patients with Staphylococcus aureus surgical site infection. Clin Infect Dis. 2003;36(5):592-8.

22. Siddiqui AH, Koirala J. Methicillin Resistant Staphylococcus Aureus (MRSA). In: StatPearls. Treasure Island (FL): StatPearls Publishing. 2020.

23. Hanberger H, Walther S, Leone M, Barie PS, Rello J, Lipman J, et al. Increased mortality associated with methicillin-resistant Staphylococcus aureus (MRSA) infection in the intensive care unit: results from the EPIC II study. Int $\mathbf{J}$ Antimicrob Agents. 2011;38(4):331-5.

24. Chen SY, Wang JT, Chen TH, Lai MS, Chie WC, Chien KL, et al. Impact of traditional hospital strain of methicillin-resistant Staphylococcus aureus (MRSA) and community strain of MRSA on mortality in patients with community-onset $\mathrm{S}$ aureus bacteremia. Medicine (Baltimore). 2010;89(5):28594.

25. Combs K, Cox K. Clinical outcomes involving patients that develop septic arthritis with methicillin sensitive staphylococcus aureus versus methicillin resistant staphylococcus aureus. J Orthop. 2017;15(1):9-12.

26. Anderson DJ, Kaye KS, Chen LF, Schmader KE, Choi Y, Sloane R, et al. Clinical and financial outcomes due to methicillin resistant Staphylococcus aureus surgical site infection: a multi-center matched outcomes study. PLoS One. 2009;4(12):e8305.

27. Cosgrove SE, Qi Y, Kaye KS, Harbarth S, Karchmer AW, Carmeli Y. The impact of methicillin resistance in Staphylococcus aureus bacteremia on patient outcomes: mortality, length of stay, and hospital charges. Infect Control Hosp Epidemiol. 2005;26(2):166-74.

28. de Kraker ME, Davey PG, Grundmann H. Mortality and hospital stay associated with resistant Staphylococcus aureus and Escherichia coli bacteremia: estimating the burden of antibiotic resistance in Europe. PLoS Med. 2011;8(10):e1001104.

29. Andreassen AES, Jacobsen CM, de Blasio B, White R, Kristiansen IS, Elstrøm P. The impact of methicillin-resistant S. aureus on length of stay, readmissions and costs: a register based case-control study of patients hospitalized in Norway. Antimicrob Resist Infect Control. 2017;6:74.

30. Macedo-Viñas M, De Angelis G, Rohner P, Safran E, Stewardson A, Fankhauser C, et al. Burden of meticillin-resistant Staphylococcus aureus infections at a Swiss University hospital: excess length of stay and costs. J Hosp Infect. 2013;84(2):132-7.

31. Zhen X, Lundborg CS, Zhang M, Sun X, Li Y, Hu X, et al. Clinical and economic impact of methicillinresistant Staphylococcus aureus: a multicentre study in China. Sci Rep. 2020;10:3900.

32. Wilke M, Hübner C, Kämmerer W. Calculated parenteral initial treatment of bacterial infections: Economic aspects of antibiotic treatment. GMS Infect Dis. 2020;8:3. 
33. Treatment Guidelines. Available at: http://www. ijmm.org/documents/Treatment_Guidelines_2019_F inal.pdf. Accessed on 20 May 2020.

34. Khilnani GC, Zirpe K, Hadda V, Mehta Y, Madan K, Kulkarni A, et al. Guidelines for Antibiotic Prescription in Intensive Care Unit. Indian J Crit Care Med. 2019;23(1):1-63.

35. Singhal T. "Rationalization of Empiric Antibiotic Therapy" - A Move Towards Preventing Emergence of Resistant Infections. Indian $\mathbf{J}$ Pediatr. 2020;87(11):945-50.

36. Robineau O, Robert J, Rabaud C, Bedos JP, Varon E, Péan Y, et al. Management and outcome of bloodstream infections: a prospective survey in 121 French hospitals (SPA-BACT survey). Infection and drug resistance. 2018;11:1359.

37. Marquet K, Liesenborgs A, Bergs J, Vleugels A, Claes N. Incidence and outcome of inappropriate inhospital empiric antibiotics for severe infection: a systematic review and meta-analysis. Crit Care. 2015;19(1):63.

38. Kim SH, Park WB, Lee CS, Kang CI, Bang JW, Kim $\mathrm{HB}$, et al. Outcome of inappropriate empirical antibiotic therapy in patients with Staphylococcus aureus bacteraemia: analytical strategy using propensity scores. Clin Microbiol Infect. 2006;12(1):13-21.

39. Nickerson EK, Wuthiekanun V, Wongsuvan G, Limmathurosakul D, Srisamang P, Mahavanakul W, et al.Factors Predicting and Reducing Mortality in Patients with Invasive Staphylococcus aureus Disease in a Developing Country. PLoS One. 2009;4(8):e6512.

40. Paul M, Kariv G, Goldberg E, Raskin M, Shaked H, Hazzan R, et al. Importance of appropriate empirical antibiotic therapy for methicillin-resistant Staphylococcus aureus bacteraemia. J Antimicrob Chemother. 2010;65(12):2658-65.

41. Schweizer ML, Furuno JP, Harris AD, Johnson JK, Shardell MD, McGregor JC, et al. Empiric antibiotic therapy for Staphylococcus aureus bacteremia may not reduce in-hospital mortality: a retrospective cohort study. PloS one. 2010;5(7):e11432.

42. Paul M, Shani V, Muchtar E, Kariv G, Robenshtok E, Leibovici L. Systematic review and meta-analysis of the efficacy of appropriate empiric antibiotic therapy for sepsis. Antimicrob Agents Chemother. 2010;54(11):4851-63.

43. Wi YM, Rhee JY, Kang CI, Chung DR, Song JH, Peck KR. Clinical predictors of methicillinresistance and their impact on mortality associated with Staphylococcus aureus bacteraemia. Epidemiol Infect. 2018;146(10):1326-36.

44. Zilberberg MD, Shorr AF, Micek ST, Chen J, Ramsey AM, Hoban AP, et al. Inappropriate Treatment of HCA-cSSTI. J Hosp Med. 2010;9;53540.

45. Shorr AF, Micek ST, Kollef MH. Inappropriate therapy for methicillin-resistant Staphylococcus aureus: resource utilization and cost implications. Crit Care Med. 2008;36(8):2335-40.

46. Chong YP, Bae IG, Lee SR, Chung JW, Jun JB, Choo $\mathrm{EJ}$, et al. Clinical and economic consequences of failure of initial antibiotic therapy for patients with community-onset complicated intra-abdominal infections. PLoS One. 2015;10(4):e0119956.

47. Szumowski JD, Cohen DE, Kanaya F, Mayer KH. Treatment and outcomes of infections by methicillinresistant Staphylococcus aureus at an ambulatory clinic. Antimicrob Agents Chemother. 2007;51(2):423-8.

48. Khawcharoenporn T, Tice A. Empiric outpatient therapy with trimethoprim-sulfamethoxazole, cephalexin, or clindamycin for cellulitis. Am J Med. 2010;123(10):942-50.

49. Bakthavatchalam YD, Rao SV, Isaac B, Manesh A, Nambi S, Swaminathan S, et al. A comparative assessment of clinical, pharmacological and antimicrobial profile of novel anti-methicillinresistant Staphylococcus aureus agent levonadifloxacin: Therapeutic role in nosocomial and community infections. Indian J Med Microbiol. 2019;37:478-87.

50. Cosimi RA, Beik N, Kubiak DW, Johnson JA. Ceftaroline for Severe Methicillin-Resistant Staphylococcus aureus Infections: A Systematic Review. Open Forum Infect Dis. 2017;4(2):84.

51. Riccobene TA, Pushkin R, Jandourek A, Knebel W, Khariton T. Penetration of ceftaroline into the epithelial lining fluid of healthy adult subjects. Antimicrob Agents Chemother. 2016;60:5849-57.

52. Tellis M, Joseph J, Khande H, Bhagwat S, Patel M. In vitro bactericidal activity of levonadifloxacin (WCK 771) against methicillin-and quinoloneresistant Staphylococcus aureus biofilms. J Med Microbiol. 2019;26:1-8.

53. Bhagwat SS, Nandanwar M, Kansagara A, Patel A, Takalkar S, Chavan R, et al. Levonadifloxacin, a Novel Broad-Spectrum Anti-MRSA Benzoquinolizine Quinolone Agent: Review of Current Evidence. Drug Design, Development and Therapy. 2019;13:4351.

54. Rodvold KA, Gotfried MH, Chugh R, Gupta M, Yeole R, Patel A, et al. Intrapulmonary Pharmacokinetics of Levonadifloxacin following Oral Administration of Alalevonadifloxacin to Healthy Adult Subjects. Antimicrob Agents Chemother. 2018;62(3):e02297-17.

55. Patel A, Sangle GV, Trivedi J, Shengule SA, Thorve D, Patil M, et al. Levonadifloxacin, a Novel Benzoquinolizine Fluoroquinolone, Modulates Lipopolysaccharide-Induced Inflammatory Responses in Human Whole-Blood Assay and Murine Acute Lung Injury Model. Antimicrob Agents Chemother. 2020;64(5):e00084-20.

56. Andersson M, Östholm-Balkhed Å, Fredrikson M, Holmbom M, Hällgren A, Berg S, et al. Delay of appropriate antibiotic treatment is associated with high mortality in patients with community-onset 
sepsis in a Swedish setting. Eur J Clin Microbiol Infect Dis. 2019;38(7):1223-34.

57. Watanakunakorn C. Mode of action and in-vitro activity of vancomycin. J Antimicrob Chemother. 1984;14:7-18.

58. Vancomycin $1 \mathrm{~g}$ Powder for Solution [package insert on the internet]. Wrexham (United Kingdom): Wockhardt UK Ltd. 2008. Available at: https://www.medicines.org.uk/emc/product/6255\#gr ef. Accessed on 14 January 2021.

59. Parenti F. Structure and mechanism of action of teicoplanin. J Hosp Infect. 1986;7:79-83.

60. Targocid $200 \mathrm{mg}$ powder [package insert on the internet]. Berkshire (UK): Aventis Pharma Limited. 1989. Available at: https://www.medicines.org. uk/emc/product/2926/smpc\#gref. Accessed on 29 July 2021.

61. Hashemian SMR, Farhadi T, Ganjparvar M. Linezolid: a review of its properties, function, and use in critical care. Drug Des Devel Ther. 2018;12:1759-67.

62. Zyvox $600 \mathrm{mg}$ film-coated tablets [package insert on the internet]. Kent: Pfizer Limited. 2001. Available at: https://www.medicines.org.uk/emc/medicine/98 57\#gref. Accessed on 29 September 2021.

63. Miller WR, Bayer AS, Arias CA. Mechanism of Action and Resistance to Daptomycin in Staphylococcus aureus and Enterococci. Cold Spring Harb Perspect Med. 2016;6(11):a026997.

64. Daptomycin $350 \mathrm{mg}$ powder [package insert on the internet]. Middlesex (UK): Accord Healthcare Limited. 2020. Available at: https://www.medicines. org.uk/emc/product/8766/smpc\#gref. Accessed on 28 October 2021.

65. Greer ND. Tigecycline (Tygacil): the first in the glycylcycline class of antibiotics. Proc (Bayl Univ Med Cent). 2006;19(2):155-61.
66. Tygacil $50 \mathrm{mg}$ powder [package insert on the internet]. Bruxelles (Belgium): Pfizer Europe. 2006. Available at: https://www.medicines.org.uk/emc/ medicine/17779/SPC/Tygacil+50mg+powder+for+s olution+for+infusion/\#gref. Accessed on 29 March 2021.

67. Murphy PB, Bistas KG, Le JK. Clindamycin. In: StatPearls [Internet]. Treasure Island (FL): StatPearls Publishing. 2021. Accessed on 01 July 2021.

68. Clindamycin $150 \mathrm{mg}$ Capsules [package insert on the internet]. Surrey (UK): Sandoz Limited. 2002. Available at: https://www.medicines.org.uk/emc/ medicine/21628\#gref. Accessed on 19 August 2021.

69. Wehrli W. Rifampin: mechanisms of action and resistance. Rev Infect Dis. 1983;5:407-11.

70. Rifampicin $300 \mathrm{mg}$ Capsules [package insert on the internet]. Hertfordshire (UK): Generics [UK] Limited t/a Mylan. 1986. Available at: https://www.medicines.org.uk/emc/product/8789/sm pc\#gref. Accessed on 03 December 2021.

71. Duplessis C, Crum-Cianflone NF. Ceftaroline: A New Cephalosporin with Activity against Methicillin-Resistant Staphylococcus aureus (MRSA). Clin Med Rev Ther. 2011;3:a2466.

72. Zinforo $600 \mathrm{mg}$ powder [package insert on the internet]. County Cork (Ireland): Pfizer Ireland Pharmaceuticals. 2012. Available at: https://www. ema.europa.eu/en/documents/product-information/ zinforo-epar-product-information_ en.pdf. Accessed on 24 April 2021.

Cite this article as: Reddy $\mathrm{PK}$, Sutar A, Sahu S, Thampi B, Keswani N, Mehta KD. Methicillin resistant Staphylococcus aureus - importance of appropriate empirical therapy in serious infections. Int J Adv Med 2022;9:56-65. 